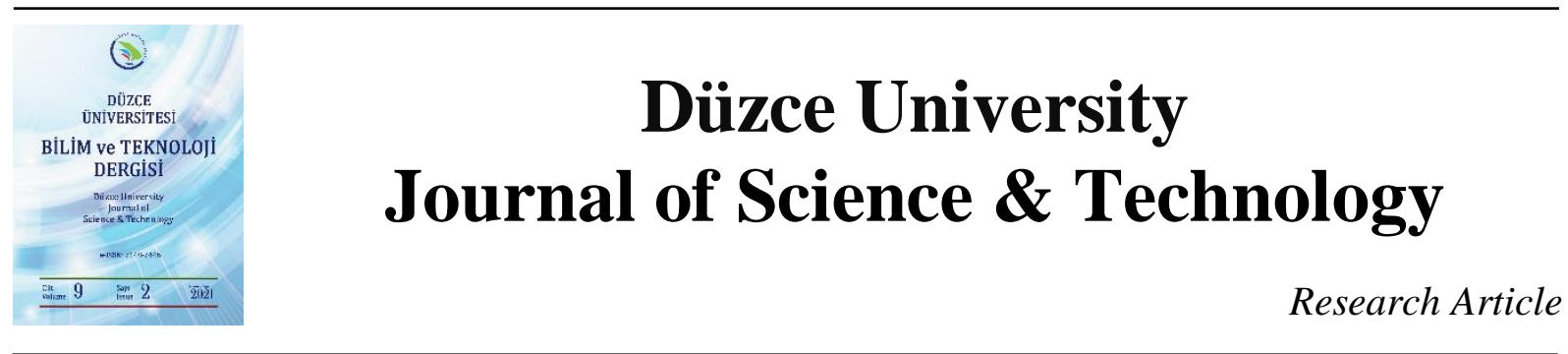

\section{Zeolite Used for Optimized Removal of Radioactive Cobalt with Response Surface Methodology}

\author{
(D) Ekrem ÇiçeKK ${ }^{\text {a,* }}$ \\ ${ }^{a}$ Department of Physics, Faculty of Art and Science, Mehmet Akif Ersoy University, Burdur, TURKEY \\ *Corresponding author's 's email address: ekrcicek@gmail.com \\ DOI: $10.29130 /$ dubited. 807860
}

\begin{abstract}
Radioactive cobalt is one of the most abundant radionuclides in radioactive waste. This study investigated the removal of radioactive cobalt $(60 \mathrm{Co})$ by adsorption with zeolite $3 \mathrm{~A}$ and $5 \mathrm{~A}$ from aqua solution. The response surface methodology was employed to constitute the predictive regression model to guess the decontamination factor for radioactive cobalt removal. The experimental maximum decontamination factor 30.37 and 15.9 were obtained for zeolite $3 \mathrm{~A}$ and zeolite $5 \mathrm{~A}$, respectively. The calculated model was significant for both zeolite $3 \mathrm{~A}$ and $5 \mathrm{~A}(\mathrm{p}<0.05)$. The predicted maximum decontamination factor was 30.05 and 15.19 in optimum conditions for zeolite $3 \mathrm{~A}$ and zeolite $5 \mathrm{~A}$, respectively. Zeolite $3 \mathrm{~A}$ has a higher adsorbent capacity than zeolite $5 \mathrm{~A}$ for the removal of radioactive cobalt from aqueous solution.
\end{abstract}

Keywords: Radioactive cobalt, Adsorption, Response surface methodology, Zeolite 3A, Zeolite 5A

\section{Zeolit Kullanılarak Uzaklaştırılan Radyoaktif Kobaltın Cevap Yüzey Yöntemi ile Optimize Edilmesi}

\begin{abstract}
ÖZET
Radyoaktif kobalt, radyoaktif atıkta en bol bulunan radyonüklidlerden biridir. Bu çalışmada, radyoaktif kobaltın (60Co) su çözeltisinden zeolit $3 \mathrm{~A}$ ve $5 \mathrm{~A}$ ile adsorpsiyon yoluyla uzaklaştıılması araştırılmıştır. Cevap yüzey yöntemi, radyoaktif kobaltın uzaklaştırılmasında dekontaminasyon faktörünü tahmin etmek için öngörücü regresyon modelini oluşturmada kullanılmıştır. Deneysel maksimum dekontaminasyon faktörü zeolit 3A ve zeolit 5A için sırasıyla 30.37 ve 15.9 olarak elde edilmiştir. Hesaplanan model zeolit $3 \mathrm{~A}$ ve $5 \mathrm{~A}$ için anlamlıydı ( $<0.05$ ). Zeolit $3 \mathrm{~A}$ ve zeolit $5 \mathrm{~A}$ için tahmin edilen maksimum dekontaminasyon faktörü, optimum koşullarda sırasıyla 30.05 ve 15.19 'dur. Sulu çözeltiden radyoaktif kobaltın uzaklaştırılmasında zeolit $3 \mathrm{~A}$, zeolit $5 \mathrm{~A}$ 'dan daha yüksek adsorban kapasitesine sahiptir.
\end{abstract}

Anahtar Kelimeler: Radyoaktif kobalt, Adsorpsiyon, Cevap yüzey yöntemi, Zeolit 3A, Zeolit 5A 


\section{INTRODUCTION}

The radioisotopes are delivered into the environment through the release of nuclear waste sewage [1]. A large number of nuclear wastes was produced by nuclear facilities. These wastes are substantial risks to the environment [2]. Many radioactive elements have a long time of half-life. They are not going to be neutralized easily [3]. Reduction of radioactive waste is necessary owing to human health problems accompanied by the aggregation of radioactive elements [4].

60Co has many beneficial applications such as materials check and sterilization. It is used to treat cancer and to sterilize medical equipment in medicine. The half-life of 60Co is 5.27 years. It is the longestlived isotope of cobalt. Owing to its long half-life, the removal of radioactive cobalt is getting more attention from researchers [5]. Elimination of 60Co from aqueous media has received great interest recently. There are many techniques to dispose of radionuclides from wastewaters [6].

One of the most effective strategies to minimize nuclear waste volumes is the selective separation of radioisotope from nuclear wastes [2]. Adsorption is favorable amid the methods owing to its easiness, thermal resistance, specific cation selectivity, and low cost [1]. Adsorbents such as zeolite have become interesting for radioactive waste management recently [7].

Zeolites are hydrated aluminosilicate minerals with crystalline microporous. Zeolite contains enormous alkaline metal ions. They have microporous and their frameworks are charged. Their anionic tetrahedral framework structures made them extremely hydrophilic sorbents. Their cavities are occupied by water molecules and charge balancing cations $[2,8]$.

Response surface methodology (RSM) is a famous experimental design method for optimization. It is a mathematical system for statistical modeling of problems [9]. It is utilized to examine the interaction between the independent variable and the dependent variable [10]. It is used for the optimization of each input variable for optimal conditions. RSM is convenient to optimize the adsorption experiments [1012].

The ever-increasing pressure to diminish the amount of radioactivity in the environment requires constant improvement of processes for the treatment of radioactive waste. The toxic nature of radioactive cobalt has been a public health problem for many years. Thence, the studies of the removal of radioactive cobalt from wastewater are important [13]. A systematic understanding of how the amount of sorbent and radioactivity participate in the adsorption process of zeolite in radioactive wastewater is still lacking [14]. The non-radioactive cobalt adsorption on zeolite $3 \mathrm{~A}$ and 5A were studied previously [15]. This study aims to show how effectively zeolite can absorb 60Co with different concentrations of solids and radioactivity. This research is focused on the thermally activated zeolite applied for effective disposal of radioactive cobalt ions from aqua solution. The adsorption process of radioactive cobalt by zeolite $3 \mathrm{~A}$ and $5 \mathrm{~A}$ adsorbents were exploited under experimental conditions. RSM was used to examine the relationships between input variables and response. The input variables are the amount of adsorbent and the initial activity of a solution.

\section{MATERIALS AND METHOD}

$3 \mathrm{~A}$ and 5A zeolites were obtained from Sigma-Aldrich. Both of them (3A and 5A) were powder. The molecular formula of zeolite $3 \mathrm{~A}$ and $5 \mathrm{~A}$ are shown as a fellow (respectively):

$\mathrm{KnNa12}-n\left[\left(\mathrm{AlO}_{2}\right) 12\left(\mathrm{SiO}_{2}\right) 12\right] \cdot x \mathrm{H}_{2} \mathrm{O}$
$\mathrm{C}_{a / n} \mathrm{Na} 12-2 n\left[\mathrm{AlO}_{2} 12\left(\mathrm{SiO}_{2}\right) 12\right] \cdot x \mathrm{H}_{2} \mathrm{O}$ 
Zeolites were activated with temperature for two hours at $873 \mathrm{~K}$ to remove water from them. Thereafter, samples were added to the radioactive cobalt and suspensions were mixed for $4 \mathrm{~h}$. Afterward, the mixtures were filtered with a syringe filter. The activities of radioactive cobalt were measured with Polon Warszawa Analyzer (A-22p HT Power supply ZW N-21M HT Control 0/2000V). A volume of $10 \mathrm{~mL}$ solution was used for all liquid radioactive cobalt reading. The radioactive measurements were repeated 10 times. The experimental decontamination factor was presented as:

$D F=A_{0} / A_{f}$

where $A_{o}$ was the initial activity of radioactive cobalt feed solution $(\mathrm{Bq} / \mathrm{L})$ and $A_{f}$ was the final activity of radioactive cobalt $(\mathrm{Bq} / \mathrm{L})$.

More information related to the experiment can be seen in previous studies [16, 17].

RSM was employed for analysis and modeling. RSM is a helpful statistical and mathematical technique as indicated by previous studies in detail [16-19].

In the RSM model, response (radioactive decontamination factor) can be described which is influenced by controllable various input factors.

The general form of RSM can be shown as:

$$
\begin{aligned}
& \hat{D} F=\beta_{0}+\beta_{1} x_{1}+\beta_{2} x_{2}+\beta_{11} x_{1}^{2}+\beta_{22} x_{2}^{2}+\beta_{12} x_{1} x_{2} \\
& \beta=\left[\beta_{0} \beta_{1} \beta_{2} \beta_{11} \beta_{22} \beta_{12}\right]^{\mathrm{T}} \\
& \beta=\left(X^{\mathrm{T}} \cdot X\right)^{-1} \cdot X^{\mathrm{T}} \cdot D F
\end{aligned}
$$

where: $\beta$-present regression coefficients;

$X$-input variables;

$D F$ - decontamination factor (response).

Adsorption of radioactive cobalt onto zeolite $3 \mathrm{~A}$;

- regression model with coded variables:

$\hat{D} F_{3 A}=12.36+6.86 x_{1}-2.20 x_{2}+6.74 x_{1}^{2}-1.51 x_{2}^{2}-3.40 x_{1} x_{2}$

subjected to: $-1 \leq x_{i} \leq+1, \quad \forall i=1,2$

- regression model with actual variables:

$$
\hat{D} F_{3 A}=-1.8-198 S D+0.00360 A_{0}+2696 S D^{2}-0.01792 S D A_{0}
$$

valid for the range: $0.05 \leq S D \leq 0.15(\% \mathrm{w} / \mathrm{v}) ; 7600 \leq A_{0} \leq 15200(\mathrm{~Bq} / \mathrm{L})$

Adsorption of radioactive cobalt onto zeolite 5A;

- regression model with coded variables:

$\hat{D} F_{5 A}=7.995+4.280 x_{1}+1.090 x_{2}+0.599 x_{1}^{2}+0.630 x_{2}^{2}+0.368 x_{1} x_{2}$

subjected to: $-1 \leq x_{i} \leq+1, \quad \forall i=1,2$ 
- regression model with actual variables:

$\hat{D} F_{5 A}=6.44+15.6 S D-0.00090 A_{0}+240 S D^{2}+0.00194 S D A_{0}$

(10)

valid for the range: $0.05 \leq S D \leq 0.15(\% \mathrm{w} / \mathrm{v}) ; 7600 \leq A_{0} \leq 15200(\mathrm{~Bq} / \mathrm{L})$

The modeling details can be found in previous studies [16-20]. Minitab 19 software was utilized for all calculations.

\section{RESULTS AND DISCUSSION}

The ANOVA was used to examine the accuracy of the calculated model. According to the results, the model was compatible where the p-value was $0.034(\mathrm{p}<0.05)$ for zeolite $3 \mathrm{~A}$. This means that the calculated model is significant for zeolite $3 \mathrm{~A}$. F value was 7.87 , it was shown that the experimental decontamination factor obtained by changing the factor levels were statistically meaningful at the $91 \%$ confidence limit. $\mathrm{R}^{2}$ value should be close to 1 for a good statistical model. The mathematical model is adequate for the prediction radioactive cobalt removal by zeolite $3 \mathrm{~A}$ sorption since $\mathrm{R}^{2}=0.91>(0.75)$. Lack of fit $F$ and $p$ values are 6.93 and 0.271 ( $p>0.05$ ), respectively.

For zeolite 5A calculated model p-value was $0.015(\mathrm{p}<0.05)$ means that the model is significant. The model $F$ value was 12.67, it was shown that the experimental decontamination factor obtained by changing the factor levels were statistically meaningful at the $94 \%$ confidence limit. The mathematical model is adequate for the prediction radioactive cobalt removal by zeolite $5 \mathrm{~A}$ since $\mathrm{R}^{2}=0.94>(0.75)$. Lack of fit $F$ and $p$ values are 37.39 and 0.120 ( $p>0.05$ ), respectively. Lack of fit was not significant and this means that the model is good [20,21].

Table 1. Radioactive cobalt experimental design for zeolite $3 \mathrm{~A}$

\begin{tabular}{|c|c|c|c|c|c|c|c|}
\hline \multirow{4}{*}{$\begin{array}{c}\text { Run } \\
\text { number } \\
(\mathrm{N})\end{array}$} & \multicolumn{4}{|c|}{ Factors (input values) } & \multicolumn{3}{|c|}{ Response } \\
\hline & \multicolumn{2}{|c|}{$\begin{array}{c}\text { Amount of sorbent } \\
(\mathrm{g} / \mathbf{1 0 0 \mathrm { ml } )}\end{array}$} & \multicolumn{2}{|c|}{$\begin{array}{c}\text { Initial activity of } \\
\text { radioactive cobalt } \mathrm{Bq} / \mathrm{L}\end{array}$} & \multirow{2}{*}{$\begin{array}{c}\text { Final } \\
\text { activity } \\
\text { Bq/L }\end{array}$} & \multicolumn{2}{|c|}{$\begin{array}{c}\text { Decontamination Factor } \\
\text { (DF) }\end{array}$} \\
\hline & & & & & & Experimental & Predicted \\
\hline & $\begin{array}{l}\text { Sorbent } \\
\text { Dosage } \\
(\% \text { w/v })\end{array}$ & $\begin{array}{c}\text { level }^{a} \\
x_{1}\end{array}$ & $\begin{array}{c}\mathbf{A}_{0} \\
(\mathbf{B q} / \mathbf{L})\end{array}$ & $\begin{array}{c}\text { level }^{\mathrm{a}} \\
\mathbf{x}_{2}\end{array}$ & & DF & DF \\
\hline 1 & 0.15 & 1 & 15200 & 1 & 952.98 & 15.95 & 18.83 \\
\hline 2 & 0.05 & -1 & 15200 & 1 & 1374.32 & 11.06 & 11.93 \\
\hline 3 & 0.15 & 1 & 7600 & -1 & 250.25 & 30.37 & 30.05 \\
\hline 4 & 0.05 & -1 & 7600 & -1 & 640.81 & 11.86 & 9.53 \\
\hline 5 & 0.15 & 1 & 11400 & 0 & 399.86 & 28.51 & 25.95 \\
\hline 6 & 0.05 & -1 & 11400 & 0 & 1057.51 & 10.78 & 12.24 \\
\hline 7 & 0.1 & 0 & 15200 & 1 & 1226.80 & 12.39 & 8.64 \\
\hline 8 & 0.1 & 0 & 7600 & -1 & 731.47 & 10.39 & 13.05 \\
\hline 9 & 0.1 & 0 & 11400 & 0 & 887.16 & 12.85 & 12.36 \\
\hline 10 & 0.1 & 0 & 11400 & 0 & 1058.50 & 10.77 & 12.36 \\
\hline
\end{tabular}

a $-1=$ low. $0=$ center. $+1=$ high. 
Table 2. Radioactive cobalt experimental design for zeolite $5 \mathrm{~A}$

\begin{tabular}{|c|c|c|c|c|c|c|c|}
\hline \multirow{4}{*}{$\begin{array}{c}\text { Run } \\
\text { number } \\
(\mathrm{N})\end{array}$} & \multicolumn{4}{|c|}{ Factors (input values) } & \multicolumn{3}{|c|}{ Response } \\
\hline & \multicolumn{2}{|c|}{$\begin{array}{l}\text { Amount of sorbent } \\
(\mathrm{g} / 100 \mathrm{ml})\end{array}$} & \multicolumn{2}{|c|}{$\begin{array}{c}\text { Initial activity of } \\
\text { radioactive cobalt } \mathrm{Bq} / \mathrm{L}\end{array}$} & \multirow{2}{*}{$\begin{array}{c}\text { Final } \\
\text { activity } \\
\text { Bq/L }\end{array}$} & \multicolumn{2}{|c|}{$\begin{array}{c}\text { Decontamination Factor } \\
\text { (DF) }\end{array}$} \\
\hline & & & & & & Experimental & Predicted \\
\hline & $\begin{array}{l}\text { Sorbent } \\
\text { Dosage } \\
(\% \text { w/v })\end{array}$ & $\begin{array}{c}\text { level }^{a} \\
x_{1}\end{array}$ & $\begin{array}{c}\mathbf{A}_{0} \\
(\mathbf{B q} / \mathbf{L})\end{array}$ & $\begin{array}{c}\text { level }^{\text {a }} \\
\mathbf{x}_{2}\end{array}$ & & DF & DF \\
\hline 1 & 0.15 & 1 & 15200 & 1 & 1000.55 & 15.19 & 14.96 \\
\hline 2 & 0.05 & -1 & 15200 & 1 & 3188.35 & 4.77 & 5.67 \\
\hline 3 & 0.15 & 1 & 7600 & -1 & 572.85 & 13.27 & 12.05 \\
\hline 4 & 0.05 & -1 & 7600 & -1 & 1761.01 & 4.32 & 4.22 \\
\hline 5 & 0.15 & 1 & 11400 & 0 & 997.81 & 11.42 & 12.87 \\
\hline 6 & 0.05 & -1 & 11400 & 0 & 2227.51 & 5.12 & 4.31 \\
\hline 7 & 0.1 & 0 & 15200 & 1 & 1463.86 & 10.38 & 9.71 \\
\hline 8 & 0.1 & 0 & 7600 & -1 & 1221.93 & 6.22 & 7.53 \\
\hline 9 & 0.1 & 0 & 11400 & 0 & 1401.32 & 8.14 & 7.99 \\
\hline 10 & 0.1 & 0 & 11400 & 0 & 1341.07 & 8.50 & 7.99 \\
\hline
\end{tabular}

Table 3. Analysis of variance (ANOVA) for the response for zeolite $3 A$

\begin{tabular}{ccccccc}
\hline Source & Sum of Squares & df & Mean Square & F-value & p-value & \\
\hline Model & 463.84 & 5 & 92.77 & 7.87 & 0.0339 & significant \\
\hline A-Sorbent Dosage & 10.55 & 1 & 10.55 & 0.8950 & 0.3977 & \\
\hline B-Initial Activity & 11.30 & 1 & 11.30 & 0.9581 & 0.3831 & \\
\hline $\mathrm{AB}$ & 46.38 & 1 & 46.38 & 3.93 & 0.1184 & \\
\hline $\mathrm{A}^{2}$ & 106.02 & 1 & 106.02 & 8.99 & 0.0400 & \\
\hline $\mathrm{B}^{2}$ & 5.35 & 1 & 5.35 & 0.4538 & 0.5375 & \\
\hline Residual & 47.16 & 4 & 11.79 & & & \\
\hline Lack of Fit & 45.00 & 3 & 15.00 & 6.93 & 0.2706 & not significant \\
\hline Pure Error & 2.16 & 1 & 2.16 & & & \\
\hline
\end{tabular}

The model F-value of 7.87 implies the model is significant for zeolite 3A. There is just a $3.39 \%$ chance that an F-value this large could occur due to noise. The lack of fit F-value of 6.93 implies the lack of fit is not significant relative to the pure error. There is a $27.06 \%$ chance that a lack of fit F-value this large could occur due to noise (Table 3 ).

Table 4. Analysis of variance (ANOVA) for the response for zeolite 5A

\begin{tabular}{ccccccc}
\hline Source & Sum of Squares & df & Mean Square & F-value & p-value & \\
\hline Model & 119.59 & 5 & 23.92 & 12.63 & 0.0146 & significant \\
\hline A-Sorbent Dosage & 0.0649 & 1 & 0.0649 & 0.0343 & 0.8621 & \\
\hline B-Initial Activity & 0.7076 & 1 & 0.7076 & 0.3737 & 0.5740 & \\
\hline $\mathrm{AB}$ & 0.5402 & 1 & 0.5402 & 0.2853 & 0.6215 & \\
\hline $\mathrm{A}^{\mathbf{2}}$ & 0.8400 & 1 & 0.8400 & 0.4436 & 0.5418 & \\
\hline $\mathrm{B}^{\mathbf{2}}$ & 0.9261 & 1 & 0.9261 & 0.4891 & 0.5229 & \\
\hline Residual & 7.57 & 4 & 1.89 & & & \\
\hline Lack of Fit & 7.51 & 3 & 2.50 & 38.63 & 0.1176 & not significant \\
\hline Pure Error & 0.0648 & 1 & 0.0648 & & & \\
\hline
\end{tabular}

The model F-value of 12.63 indicates the model is significant for zeolite $5 \mathrm{~A}$. There is just a $1.46 \%$ chance that an F-value this large could occur due to noise. The lack of fit F-value of 38.63 implicates the lack of fit is not significant relative to the pure error. There is an $11.76 \%$ chance that a lack of fit Fvalue this large could occur due to noise (Table 4). 

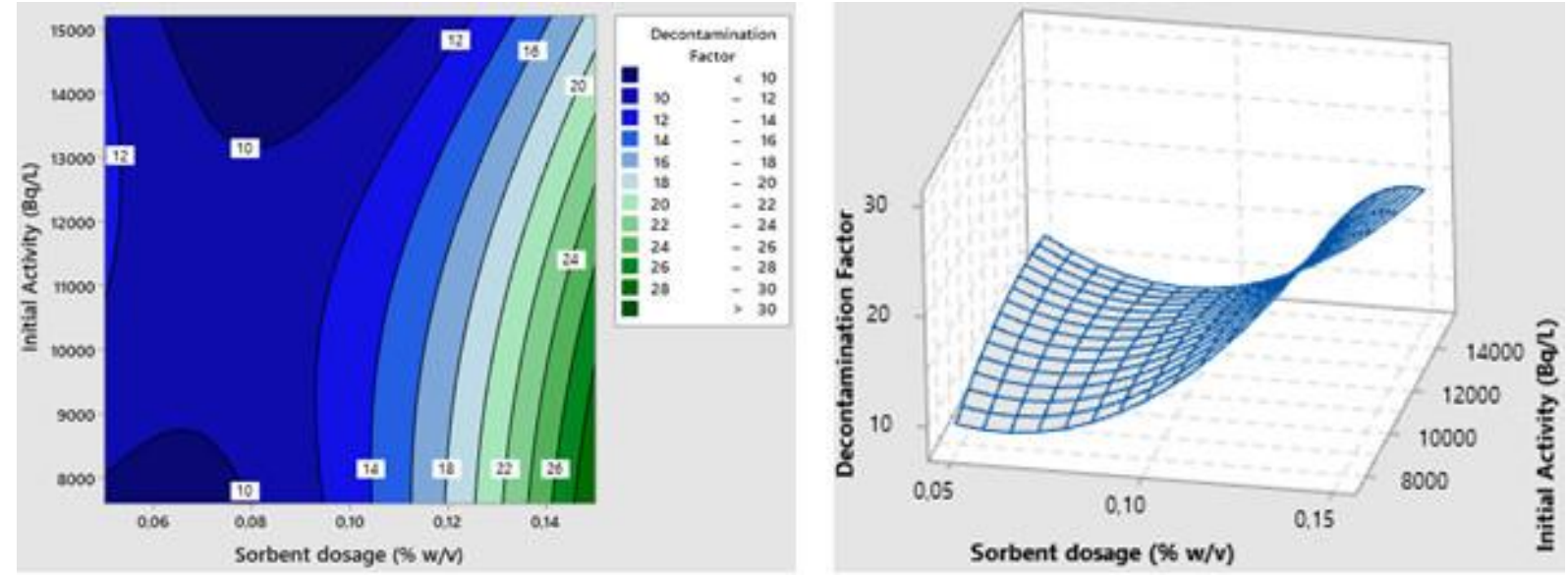

Figure 1. Zeolit $3 A$ - radioactive cobalt contour plot and response surface plot for decontamination factor.
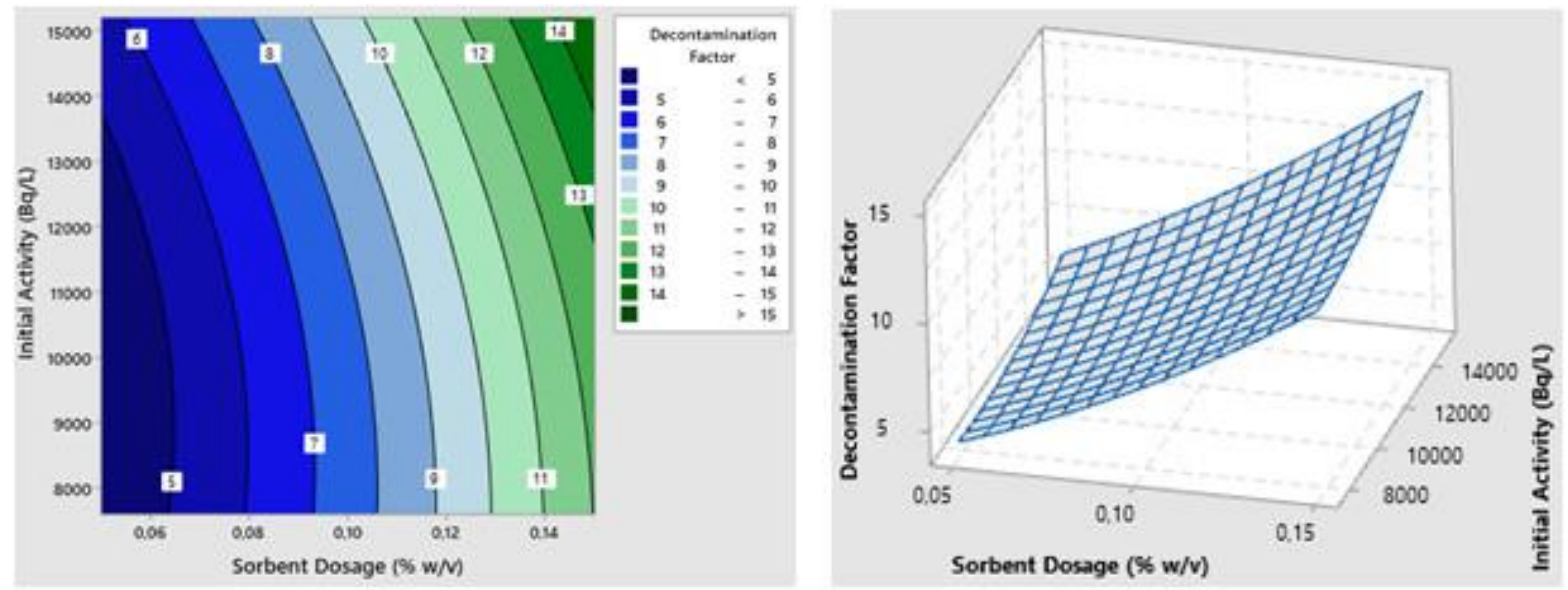

Figure 2. Zeolit 5A - radioactive cobalt contour plot and response surface plot for decontamination factor.

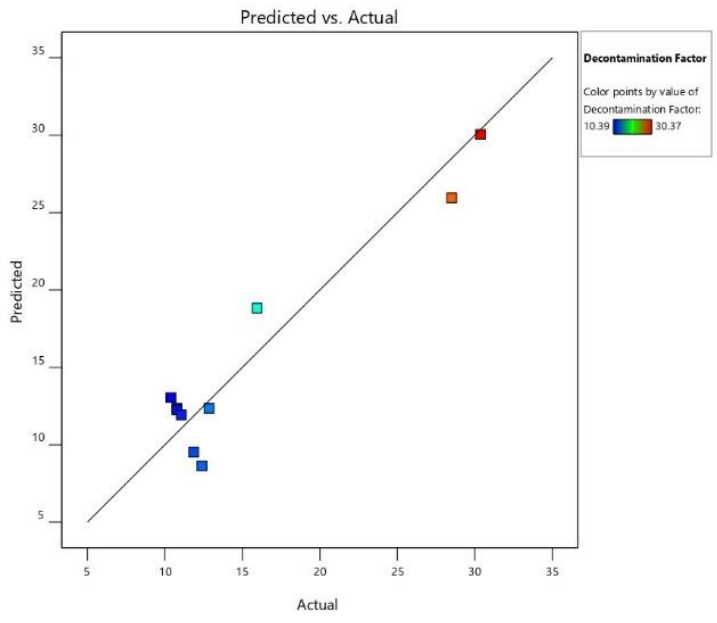

Figure 3. Predicted and actual decontamination factor for zeolite $3 A$ 


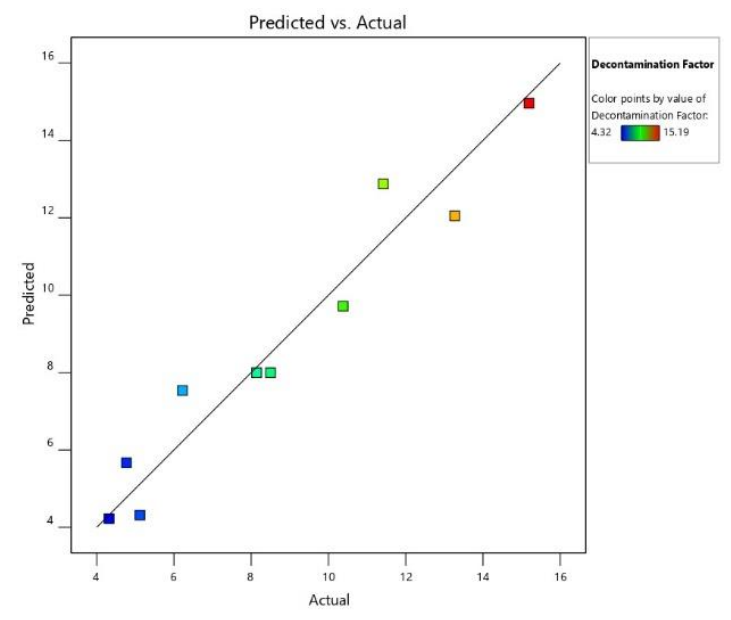

Figure 4. Predicted and actual decontamination factor for zeolite $5 \mathrm{~A}$

Figure 1 shows the radioactive cobalt contour plot and response surface plot for the decontamination factor for zeolite $3 \mathrm{~A}$. The counter map demonstrates the decontamination factor interconnection amid the sorbent quantity and initial radioactive cobalt concentration. The increasing of sorbent dosage will give enhanced values of the decontamination factor. However, increasing of initial cobalt concentration will diminish the decontamination factor for zeolite 3A. Decontamination factor is growing for higher sorbent dosage (i.e. SD > $0.1 \% \mathrm{w} / \mathrm{v}$ ). The interaction among the input variables and response (decontamination factor) can be seen in the three-dimensional response surface plot for radioactive cobalt adsorption in figure 1 .

The optimal condition was observed to be $\mathrm{A}_{0}=7600 \mathrm{~Bq} / \mathrm{L}$ and $\mathrm{SD}=0.15 \mathrm{w} / \mathrm{v}$ for radioactive cobalt adsorption on zeolite $3 \mathrm{~A}$. The maximum computed decontamination factor was 30.05 in optimal condition. The experimental corresponding value (decontamination factor) was 30.37 for the same condition (Table 1).

Figure 2 shows the radioactive cobalt contour plot and response surface plot for the decontamination factor for zeolite 5A. The decontamination factor is increasing while sorbent dosage is rising. The decontamination factor is growing while the initial cobalt concentration is increasing for higher sorbent dosage (i.e. SD > $0.1 \% \mathrm{w} / \mathrm{v}$ ).

For the $5 \mathrm{~A}$ sorbent. the optimal condition was determined to be $\mathrm{A}_{0}=15200 \mathrm{~Bq} / \mathrm{L}$ and $\mathrm{SD}=0.15 \mathrm{w} / \mathrm{v}$. The maximum decontamination factor was predicted as 14.96 in this condition. The experimental decontamination factor corresponds to 15.19 for the same condition (Table 2).

The experimental minimum decontamination factor was 10.39 for $0.1 \%$ w/v sorbent dosage and 7600 $\mathrm{Bq} / \mathrm{L}$ initial cobalt activity for zeolite $3 \mathrm{~A}$. The predicted value in the same input variables corresponds to 13.05. In the case of zeolite 5A. the experimental minimum decontamination factor was 4.32 for 0.05 $\mathrm{g}$ sorbent dosage and $7600 \mathrm{~Bq} / \mathrm{L}$ initial cobalt activity.

Figures 3 and 4 demonstrate the predicted and actual decontamination factor for zeolite 3A and 5A, respectively. As seen from the figures predicted values are very close to actual values (Figures 3 and 4).

The calculated value is 4.22 (predicted) in the same condition for zeolite 5A. The sorbent dosage has a certain effect on response (decontamination factor) for both sorbents (zeolite 3A and zeolite 5A). According to our experimental result. decontamination capacity of zeolite $3 \mathrm{~A}$ is higher than the zeolite $5 \mathrm{~A}$.

Due to their high radiation stability and extreme selectivity, zeolites are useful for the removal of radioisotopes from nuclear wastewater. The more the adsorbent dosage will result the better the 
decontamination factor. Determination of the optimum quantity of adsorbent is a key parameter and affects the whole adsorption process [2,3]. The main adsorption mechanism is that cations in the zeolite structure can exchange with cations in the radioactive solutions freely through the cavities [14]. RSM is an effective mathematical tool to assess the effect of the input variables and their interactions on the dependent variable (response) [12].

\section{CONCLUSIONS}

In this study. we investigated the ability of removal of the radioactive cobalt by zeolite $3 \mathrm{~A}$ and $5 \mathrm{~A}$ in aqua solution. The maximum experimental decontamination factor was 30.37 and 15.9 for zeolite $3 \mathrm{~A}$ and zeolite 5A, respectively. Zeolite $3 \mathrm{~A}$ demonstrates stronger adsorption than zeolite $5 \mathrm{~A}$ because the network-like structure contains small pores. RSM was used to describe input variables (Sorbent dosage and initial activity) relationship with the response (Decontamination factor). Our results denoted that molecular sieves lead to a large amount of removal of radioactive cobalt ions from aqua solution. We presented that both zeolite $3 \mathrm{~A}$ and $5 \mathrm{~A}$ might be used as an adsorbent for the removal of radioactive cobalt in radioactive wastewater. It was found that zeolite showed much better performance for cobalt removal from aqua solution as compared to other adsorbents such as pumice. Response surface methodology is high accuracy and great prediction performance.

\section{REFERENCES}

[1] M.W. Munthali, E. Johan, H. Aono and N. Matsue, "Cs+and Sr2+Adsorption selectivity of zeolites in relation to radioactive decontamination," Journal of Asian Ceramic Societies, vol. 3, no. 3, pp. 245-250, 2015.

[2] H.Y. Lee, H.S. Kim, H.K. Jeong, M. Park, D.Y. Chung, K.Y. Lee, E.H. Lee and W.T. Lim, "Selective removal of radioactive cesium from nuclear waste by zeolites: On the origin of cesium selectivity revealed by systematic crystallographic studies," The Journal of Physical Chemistry, vol. 121, no. 19, pp. 10594-10608, 2017.

[3] M. Sadeghi, S. Yekta, H. Ghaedi and E. Babanezhad, "Effective removal of radioactive 90Sr by $\mathrm{CuO}$ NPs/Agclinoptilolite zeolite composite adsorbent from water sample: Isotherm, kinetic and thermodynamic reactions study," The International Journal of Industrial Chemistry, vol. 7, pp. 315331, 2016.

[4] H.M. Saleh, H.R. Moussa, H.H. Mahmoud, F.A. El-Saied, M. Dawoud and R.S.A. Wahed, "Potential of the submerged plant myriophyllum spicatum for treatment of aquatic environments contaminated with stable or radioactive cobalt and cesium," Progress in Nuclear Energy, vol. 118, pp. $103147,2020$.

[5] E. Hernfindez-Barrales and F. Granados-Correa, "Sorption of radioactive cobalt in natural mexican clinoptilolite," Journal of Radioanalytical and Nuclear Chemistry, vol. 242, no. 1, pp. 111114, 1999.

[6] Q.Q. Zhong, Y.Q. Zhao, L. Shen, B. Hao, X. Xu, B.Y. Gao, Y.N. Shang, K.Z. Chu, X.H. Zhang and Q.Y. Yue, "Single and binary competitive adsorption of cobalt and nickel onto novel magnetic composites derived from green macroalgae," Environmental Engineering Science, vol. 37, no. 3, pp. 188-200, 2020. 
[7] S. Hasan, A.R.M. Iasir, T.K. Ghosh, B.S. Gupta and M.A. Prelas, "Characterization and adsorption behavior of strontium from aqueous solutions onto chitosan-fuller's earth beads," Healthcare, vol. 7, pp. 52-70, 2019.

[8] S. Ovhal, I.S. Butler and S. Xu, "The potential of zeolites to block the uptake of radioactive strontium-90 in organisms," Contemporary Chemistry, vol. 1, no. 1, pp. 1-13, 2018.

[9] N. Manmai, Y. Unpaprom and R. Ramaraj, "Bioethanol production from sunflower stalk: Application of chemical and biological pretreatments by response surface methodology (RSM)," Biomass Conversion and Biorefinery, 2020. doi: 10.1007/s13399-020-00602-7

[10] Y. Yang, Z. Zheng, D. Zhang and X. Zhang, "Response surface methodology directed adsorption of chlorate and chlorite onto miex resin and study of chemical properties," Environmental Science Water Research \& Technology, vol. 6, pp. 2454-2464, 2020.

[11] J. Lin, B. Su, M. Sun, B. Chen and Z. Chen. "Biosynthesized iron oxide nanoparticles used for optimized removal of cadmium with response surface methodology," Science of the Total Environment, vol. 627, pp. 314-321, 2018.

[12] J.C. Martínez-Patiño, B. Gullón, I. Romero, E. Ruiz, M. Brnčić, J.S. Žlabur and E. Castro, "Optimization of ultrasound-assisted extraction of biomass from olive trees using response surface methodology," Ultrasonics Sonochemistry, vol. 51, pp. 487-495, 2019.

[13] H.S. Hassan, S.H. Kenawy, G.T. El-Bassyouni, E.M.A. Hamzawy and R.S. Hassan, "Sorption behavior of cesium and europium radionuclides onto nano-sized calcium silicate," Particulate Science and Technology, vol. 38, no. 1, pp. 105-112, 2020.

[14] X.H. Fang, F. Fang, C.H Lu and L. Zheng, "Removal of Cs+, Sr2+, and Co2+ ions from the mixture of organics and suspended solids aqueous solutions by zeolites," Nuclear Engineering and Technology, vol. 49, no. 3, pp. 556-561, 2017.

[15] E. Cicek, E. Aras, I. Bayrakli, B. Dede and A. Kilic, "The determination and modeling of the removal efficiencies of cobalt on zeolite 3A and 5A," 4th International Conference on Radiation Interaction with Material and Its Use in Technologies, Kaunas, Lithuania, 2012, pp. 77-80

[16] E. Cicek, C. Cojocaru, G. Zakrzewska-Trznadel, M. Harasimowicz and A. Miskiewicz, "Response surface methodology for the modeling of $85 \mathrm{Sr}$ adsorption on zeolite $3 \mathrm{~A}$ and pumice," Environmental Technology, vol. 33, no. 1, pp. 51-59, 2012.

[17] E. Cicek, C. Cojocaru, G. Zakrzewska-Trznadel, A. Jaworska and M. Harasimowicz, "Response surface methodology for cobalt removal from aqua solutions using Isparta pumice and zeolite 4A adsorbents," Nukleonika, vol. 53, no. 2, pp. 121-128, 2008.

[18] C. Cojocaru and M. Macoveanu, "Modeling and optimization of diesel oil spill removal from water surface using shredded strips of polypropylene as the sorbent," Environmental Engineering and Management Journal, vol. 2, no. 2, pp. 145-154, 2003.

[19] M. Khayet, C. Cojocaru and G. Zakrzewska-Trznadel, "Response surface modelling and optimization in pervaporation," Journal of Membrane Science, vol. 321, pp. 272-283, 2008.

[20] B. Chauhan and R. Gupta, "Application of statistical experimental design for optimization of alkaline protease production from bacillus sp. RGR-14". Process Biochemistry, vol. 39, no. 12, pp. 2115-2122, 2004. 
[21] M.H. Le, S.K. Behera and H.S. Park, "Optimization of operational parameters for ethanol production from Korean food waste leachate," International Journal of Environmental Science \& Technology, vol. 7, 157-164, 2010. 